that of Joseph Tainter in his 1988 book The Collapse of Complex Societies, which has long been the best-known book on the subject. Tainter developed a convincing argument that societies actually advance or 'complexify' as they respond creatively to major challenges. He therefore found it difficult to accept that any complex society with predeveloped administrative, organizational and technical coping skills would allow itself to succumb to emergent ecological problems. Instead, he placed the blame for collapse on socio-political instability resulting from diminishing returns to investment in problem solving - that is, on excessive complexity. Diamond concedes that the implosion of a vulnerable society might be triggered by an overstretched economy, dissolute leadership or enemy invasion, say, but argues that the ultimate cause is usually fragility caused by ecological degradation.

In the book's final section, Diamond focuses on practicallessons. Why do societies sometimes make such disastrous decisions? What can we 'moderns' usefully learn from the responses of ancient societies to environmental crises? What is the appropriate role of the private sector, transnational corporations in particular? Which of today's environmental trends are the most threatening and how do they differ from those that sank previous societies? Anticipating resistance to his findings from perennial optimists, Diamond includes well reasoned ripostes to a dozen common 'one-liner' objections to the seriousness of environmental problems and to the relevance of previous collapses to techno-industrial society.

In the end, Diamond's painstaking toil in the deep mines of history rewards him with sufficient nuggets of hope that he emerges "cautiously optimistic" about the human prospect. Modern society's ecological and geopolitical problems may be daunting but, in theory, they can be solved if we take the right decisions to reduce our ecological footprints. And let's not forget that we are uniquely positioned to learn from the collapse of previous societies.

Regrettably, theory and example do not always translate into practice. The most important lesson to be drawn from Collapse is that resilient societies are nimble ones, capable of long-term planning and of abandoning deeply entrenched but ultimately destructive core values and beliefs. This, in turn, requires a well informed public, inspired leadership and the political will to take decisions that go against the established order of things. In this light, the astute observer of contemporary geopolitics and ecological decline might be excused a descent into quiet despair.

William Rees is professor of ecological planning in the School of Community and Regional Planning, University of British Columbia, 6333 Memorial Road, Vancouver V6T 1Z2, Canada.

\section{A natural pioneer}

John James Audubon: The Making of an American

by Richard Rhodes

Knopf: 2004.528 pp. $\$ 30$

\section{John Fitzpatrick}

Some of the best-known icons of America's pioneer age endure through bloated mythologies of heroism generated by salesmanship and an American culture perpetually in demand of larger-than-life heroes. Not so John James Audubon, the most famous naturalist-artist in history. His monumental double-elephant folio production Birds of America holds a deserved place among the greatest artistic achievements of any era, and his writings provide our richest chronicle of North American natural history before the industrial revolution.

The mythology surrounding Audubon's life and character bestows on him a mixed review: mysterious birth and early childhood, commercial failure and debtors' prison, and long absences from his family. Audubon the legend has been painted as a bumbling businessman, a self-promoting dandy and a gallivanting nature-boy who abandoned wife and children for long periods to live in the woods and sketch birds. Audubon's serendipitous good fortune in marrying a patient and hard-working wife, Lucy Bakewell, and later becoming a partner with virtuoso engravers the Robert Havells, senior and junior, carry as much weight in fable as do his keen observational skills, passionate creativity, breakthrough artistic genius and scientific contributions.

In this masterful biography, the historian and novelist Richard Rhodes systematically debunks these persistent canards. This is a lively, interpretative tour through the personality, travels, business ventures, accomplishments and foibles of an extraordinary man. Beginning with Audubon's illegitimate birth in Saint-Domingue (now Haiti) in 1785 , Rhodes weaves together each turn of Audubon's difficult but colourful 61-year life with insightful commentary and vignettes that illustrate what life was like in the forested frontier west of the Appalachians. He underscores the turbulent social and economic forces at work in both Europe and America during the early nineteenth century.

Supported by generous quotes from his copious journals and correspondence, the Audubon we see here was a multi-talented, complex, hard-working and genuinely heroic family man. Handsome and lively - "his eyes alone commanded attention" - he had unrivalled physical dexterity and energy, loved to sing and dance, played the violin and flute, and excelled at fencing, marksmanship, horsemanship and - of course - art. Everyone he met remembered him vividly, and Rhodes' intimate portrait leaves little doubt that the reader would love to have known this man personally.

Rhodes casts Audubon's most famous business failures as earnest and promising ventures that collapsed at precisely the same moments, and for the same reasons, as virtually every other similar business in the country. After a shipping partnership in New Orleans was destroyed by embargoes caused by the war of 1812, Audubon successfully built up a new one along the rapidly developing Ohio River. Then, during America's first major economic depression (the panic of 1819), nearly every mercantile business in the country collapsed. Returning home after failing to collect a debt in New Orleans,

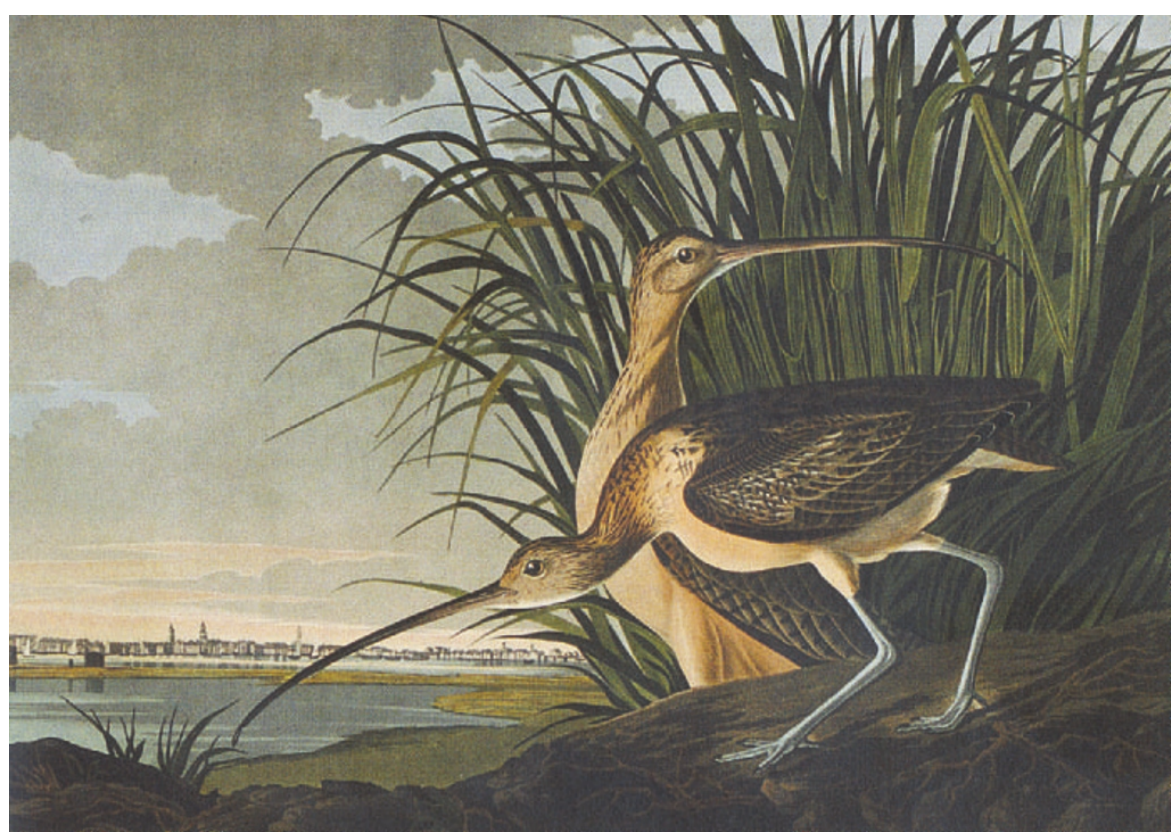

An eye for detail: this image of long-billed curlew is typical of Audubon's bird paintings. 
Audubon "took an upriver Mississippi steamboat to the mouth of the Ohio and walked the last 130 miles home".

The heart of the story begins here, as the 32-year-old Audubon plunges from prosperous Ohio gentleman to a penniless, depressed woodsman with a growing family to feed. With understated epiphany - "nothing was left to me but my humble talents" - he soon excelled at drawing portraits of wealthy citizens, while keeping alive his obsessive passion for birds. Long before imagining how he would use them, Audubon had been creating a portfolio of masterpieces. His life-sized paintings of birds were not the stiff scientific illustrations then in fashion. A keen observer, Audubon committed himself early to capturing (often by exaggeration) each bird's species-specific personality. In 1810, Alexander Wilson, the 'father of American ornithology' but a depressed loner, encountered Audubon in Louisville. Jealous of the young artist's superior talent, Wilson refused Audubon's offer to collaborate, and died just three years later. But Wilson's big idea — to travel about America painting and writing about its birds - left a lasting impact. As he began to paint for a living, Audubon realized his calling and single-mindedly pursued Wilson's idea. By 1926 he was sailing for England to find an engraver and begin publication, and he would soon leave Wilson in the dust.

Rhodes traces the artist's meteoric rise as England embraced both the art and the man. Audubon's revolutionary paintings portrayed highly animated birds in exacting detail, reflecting frontier America in vivid, even bloody, colour. His detailed knowledge about the lives of mostly unfamiliar birds impressed England's stuffy scientific circles. Audubon's dogged pursuit of a one-man business demanded a long and punishing schedule. Rhodes gives haunting, nuanced colour to the picture of Audubon in England, struggling to gain credibility and subscribers. Steadily achieving fame, the artist is wracked with depression, self-doubt, changes of plans and sadness. We see him as a passionate, profoundly tender man who deeply misses his wife. Anyone who thinks they know the travails of a relationship at a distance should read what these two lovers endured, at a time when their frequent letters to each other either disappeared or took six months to be delivered.

I found it only mildly disappointing that Audubon's scientific relationships and contributions are treated more lightly than his personal and business affairs. We are given glimpses, for example, of his election as a fellow of the Royal Society of London (only the second American, after Benjamin Franklin), his brief association with William Swainson, his long friendship with Charles Bonaparte, his enmity with George Ord and the Philadelphia establishment, and his close partnership with naturalist John Bachman

\section{What's in the flask?}

\section{The origin of the archetypal image of the chemist.}

\section{Philip Ball \\ What are these scientists all looking at? The arche- typal image of the chemist, ubiquitous in stock photo- graphic images today, and even in clip-art databases, depicts a lab-coated figure gazing at a flask of liquid held aloft. The inclusion of the picture in the bottom right will be understood by British readers, who may recognize the features of a woman who went on to become the country's prime minister.}

But this is not what real chemists spend their time doing. So where does the pose come from? As Joachim Schummer and Tami Spector pointed out at a recent conference in Paris on the public image of chemistry, the answer lies in the image in the top left. This appeared in a book dating from 1283, the Latin translation of Avicenna's Canon of Medicine, and shows not a chemist but a doctor. The flask contains not a solution synthesized by alchemy but a sample of a patient's urine - diagnoses were typically made by uroscopy, the practice of inspecting the urine for colour, clarity and other qualities.

When Paracelsus introduced chemistry into medicine (so-called iatrochemistry) in the early seventeenth century, this image of the gazed-at flask transferred itself from medicine to 'chymistry', and subsequently became so much a part of the subject's visual language that is alive and well today.

Philip Ball is a consultant editor for Nature. 1 www.hyle.org/service/chmc2004/

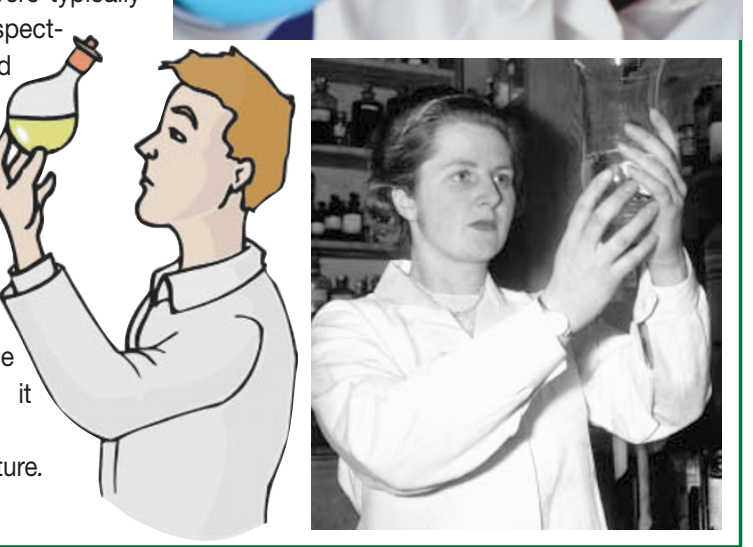

of Charleston. But we barely meet William MacGillivray of Edinburgh, with whom Audubon wrote the five-volume Ornithological Biography, his most important and lasting scientific achievement.

The book contains numerous errors of nomenclature, and would have benefited from proofreading by an ornithologist. Most disappointing of all to me are the illustrations, which are mostly small black-andwhite pictures, many untitled. The printing quality of the 16 colour plates is abysmal Audubon would never have approved them for public release.

Rhodes has significantly clarified both the factual record and the human understanding become synonymous with birds. Of French descent and English fame, Audubon became a consummate American who realized that his work would become immortal as his beloved frontier began disappearing. Indeed, with each passing year, Audubon's legacy will add immeasurably to the world's deep appreciation for his passion.

John Fitzpatrick is at the Cornell Laboratory of Ornithology, Ithaca, New York 14850, USA.

\section{More on Audubon}

Under a Wild Sky by William Souder

North Point Press: 2004. \$25. of this truly legendary man whose name has continues to multiply in value, and this book 